Article

\title{
History of East European Chernozem Soil Degradation; Protection and Restoration by Tree Windbreaks in the Russian Steppe
}

\section{Yury G. Chendev ${ }^{1}$, Thomas J. Sauer ${ }^{2, *}$, Guillermo Hernandez Ramirez ${ }^{3}$ and Charles Lee Burras ${ }^{4}$}

1 Department of Natural Resources Management and Land Cadastre, Belgorod State University, Belgorod 308015, Russia; E-Mail: chendev@bsu.edu.ru

2 USDA-ARS, National Laboratory for Agriculture and the Environment, Ames, IA 50011, USA

3 Department of Renewable Resources, University of Alberta, Edmonton, AB T6G 2R3, Canada; E-Mail: ghernand@ualberta.ca

4 Department of Agronomy, Iowa State University, Ames, IA 50011, USA; E-Mail: 1burras@iastate.edu

* Author to whom correspondence should be addressed; E-Mail: tom.sauer@ars.usda.gov; Tel.: +1-515-294-3416; Fax: +1-515-294-8125.

Academic Editor: Marc A. Rosen

Received: 30 October 2014 / Accepted: 29 December 2014 / Published: 8 January 2015

\begin{abstract}
The physiographic region of the Central Russian Upland, situated in the Central part of Eastern Europe, is characterized by very fertile grassland soils-Chernozems (Mollisols in the USDA taxonomy). However, over the last several centuries this region has experienced intense land-use conversion. The most widespread and significant land-use change is the extensive cultivation of these soils. As a result, Chernozems of the region that were some of the most naturally fertile soils in the world with thick A horizons had become, by the second half of the 19th century, weakly productive, with decreased stocks of organic matter. When not protected by plant cover, water and wind erosion degraded the open fields. The investigation of methods for rehabilitation and restoration of Chernozems resulted in the practice of afforestation of agricultural lands (mainly by windbreak planting). Preferences of agroforestry practices were initially connected with protection of cropland from wind and water erosion, improvement of microclimate for crop growth, and providing new refugia for wild animal and plant habitats. During the last several decades, tree windbreaks have begun to be viewed as ecosystems with great potential for atmospheric carbon sequestration, which plays a positive role in climate change mitigation. For the
\end{abstract}


evaluation of windbreak influence on Chernozem soils, a study was developed with three field study areas across a climatic gradient from cool and wet in the north of the region to warm and dry in the south. Windbreak age ranged from 55-57 years. At each site, soil pits were prepared within the windbreak, the adjacent crop fields of 150 years of cultivation, and nearby undisturbed grassland. Profile descriptions were completed to a depth of $1.5 \mathrm{~m}$. A linear relationship was detected between the difference in organic-rich surface layer $(\mathrm{A}+\mathrm{AB}$ horizon) thickness of soils beneath windbreaks and undisturbed grasslands and a climate index, the hydrothermal coefficient (HTC). These results indicate that windbreaks under relatively cooler and wetter climate conditions are more favorable for organic matter accumulation in the surface soil. For the $0-100 \mathrm{~cm}$ layer of the Chernozems beneath windbreaks, an increase in organic $\mathrm{C}$ stocks comparable with undisturbed grassland soils (15-63 $\mathrm{Mg} \cdot \mathrm{ha}^{-1}$ ) was detected. Significant growth of soil organic matter stocks was identified not only for the upper $30 \mathrm{~cm}$, but also for the deeper layer $(30-100 \mathrm{~cm})$ of afforested Chernozems. These findings illustrate that, in the central part of Eastern Europe, tree windbreaks improve soil quality by enhancing soil organic matter while providing a sink for atmospheric carbon in tree biomass and soil organic matter.

Keywords: Russian Chernozems; soil organic carbon; degradation of soils; restoration of soils; afforestation

\section{Introduction}

One of the main natural resources of Russia are its Chernozem soils or Chernozems. The history of soil science evolved from studies of these soils. The founder of soil science, Vasily Dokuchaev called Chernozems the "Tsar of soils" [1]. As for any other science, the foundation of soil science was connected with "demands of practice". In 1876, the Free Economic Society of Russia, with support of the Russian government, developed a project to study the causes that led to agricultural depletion of Chernozems. The research program included detailed study of Chernozems, their properties, formation, and patterns of spatial distribution within Eastern Europe. A young Quaternary Geologist, V.V. Dokuchaev, was selected as research leader of this project. During the several years following the execution of the project, he had proposed and argued the main foundations of pedology or soil science using the example of Chernozem soils [2]:

- The soil is an important separate component of the environment with its own history of development, connected by properties and processes with other components of the environment;

- The soil is a product of influence of soil forming factors: parent material, relief, climate, plants and animals, and age of the territory;

- The soil consists of a few genetically interrelated layers or horizons with individual properties, reflecting the history of soil formation;

- The soil is a mirror of the environment, the focus of all natural processes which form landscapes and biosphere in the whole. 
Further (after 1883) development of soil science in Russia was associated with expeditions by Dokuchaev and his students with different goals: soil cartography and descriptions of soils in a series of administrative Russian units (provinces), study of soil zones (elevation zones in mountain systems), and the founding of special scientific stations for long term instrumental observations of soil properties and soil regimes in different climatic zones [3]. However, one of the most important activities of Dokuchaev at the end of the 19th century was organization of the so-called "Special Expedition" to Kamennaya Steppe of the Voronezh province to study the effects of a drought that affected the southern provinces of European Russia in 1891-1892. Detailed studies of all components of the environment in the Kamennaya Steppe led Dokuchaev to the scientific evaluation of the idea for the necessity of agroforestry within steppe landscapes, crop fields and grasslands - to improve the soil resistance to adverse climatic changes and to improve their productivity [4]. Since this time, Russia began to systematically introduce agroforestry as an effective way to protect soils from erosion and improve soil and climate conditions for increasing crops yields.

Until the end of the 1940s, many agroforestry activities within steppe agricultural lands were concentrated in experimental scientific stations such as Kamennaya Steppe. Only in the 1950-1960s did afforestation become public agricultural policy in the Soviet Union [5]. The "Plan for the Transformation of Nature" - a comprehensive program of scientific management of nature in the Soviet Union was implemented in the late 1940s. The plan was adopted on the initiative of Stalin and put into effect the decision of the Council of Ministers of the USSR on 20 October 1948 as "On the plan of shelterbelts, the introduction of grass crop rotations, construction of ponds and reservoirs to ensure high crop yields in the steppe and forest-steppe regions of the European part of the USSR". In print, the document is called "Stalin's Plan for the Transformation of Nature". The plan was unprecedented in the global experience in terms of scale. The program included a plan to plant windbreaks to block the hot, dry winds and together with ponds and reservoirs to increase water storage and ameliorate climate change in an area of more than 120 million hectares, which is equal to the total territory of England, France, Italy, Belgium and the Netherlands (Figure 1). The centerpiece of the plan was field-protective afforestation and irrigation. In the course of the project, afforestation of agricultural lands covered four major watershed basins of the rivers Dnieper, Don, Volga, and Ural in the European South of Russia. The first designed windbreak was to stretch from the Ural Mountains to the shores of the Caspian Sea, with a length of more than a thousand kilometers. The most intensive planting of windbreaks took place in 1949-1953 when 2.1 million hectares of windbreaks were planted. In the 1950-1960s, afforestation of the Southern part of Eastern Europe continued, but not as intensively as from 1949-1953. The main result of this State plan for agricultural lands afforestation was an ecological situation of stabilization as well as in increase of crop yields [5].

Given this background, what were the reasons for degradation of Chernozem soils that were the impetus for the emergence of soil science, and then the introduction of windbreak planting? The answer to this question can be found in the history of natural and soil resource management. As a model region, we can observe one subject of the Russian Federation, Belgorod Oblast, located on the southern slopes of the Central Russian Upland. Of the $27,134 \mathrm{~km}^{2}$ area of Belgorod Oblast, $77 \%$ has Chernozem soils [6]. Economic development of the Belgorod Oblast (as in many regions of the South of European Russia) began in the end of 16th-early 17th centuries. Notable anthropogenic changes of the steppe vegetation began in the 16th century with the beginning of the construction of Tatar roads [7], although 
some lands remained unsettled for a long time. Substantial transformations of steppe vegetation during this time were caused by destruction of natural steppe vegetation on Tatar roads, and fires on the steppes.

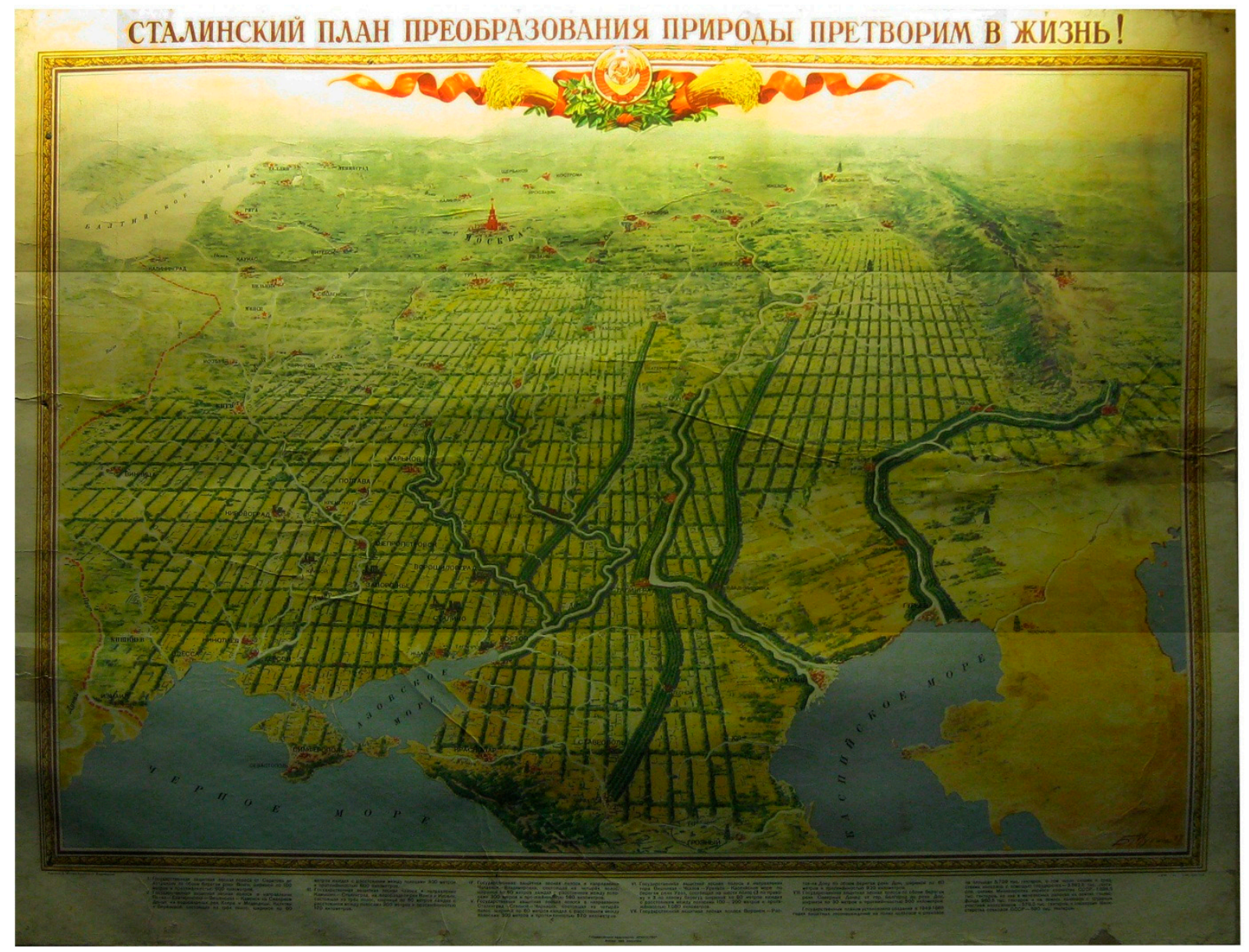

Figure 1. Poster showing the plan for the steppe zone transformation in the European part of the USSR through afforestation according to plan of 1948 (photo from the Museum of Kamennaya Steppe).

Transformation of forests in relation to the steppe transformation occurred quickly. First, forests were affected by construction of settlements and fortifications. At the end of 17 th to the first half of the 18 th century, forests were reduced significantly to build the Azov-Black Sea fleet [8]. In the 18th century, the average annual consumption of wood had increased by at least five times as compared with the 17th century. Figure 2 provides a visual representation of the spatial and temporal variation of the natural vegetation changes within Belgorod Oblast over the past 400 years. Areas of forest and virgin steppe declined, being replaced by settlements, arable lands, and pastures. Calculations on maps show that in the 1780 s virgin steppes occupied about $22 \%$ of the total area, and forest only $16 \%$. By the middle of 19 th century, forests covered $13 \%$ of the area and the area of untilled steppes dramatically decreased to just a few percent. In the 1880s, the last virgin steppe areas were plowed except for accidentally surviving islets of steppes in the eastern and northern parts of Belgorod Oblast, which now have the status of natural reserves. The last large-scale deforestation ended in 1917, after which the area of forests varied only slightly, accounting for about $8 \%$ of the area. Currently, forest harvests continue to be carried out with selective felling of trees, so the age of trees is young (the vast majority of trees less than 80 years). 
Artificial planting of Scots pine (Pinus sylvestris) on sandy river terraces of the study area [9] can be considered a positive anthropogenic effect of man's influence to restore lost elements of flora.
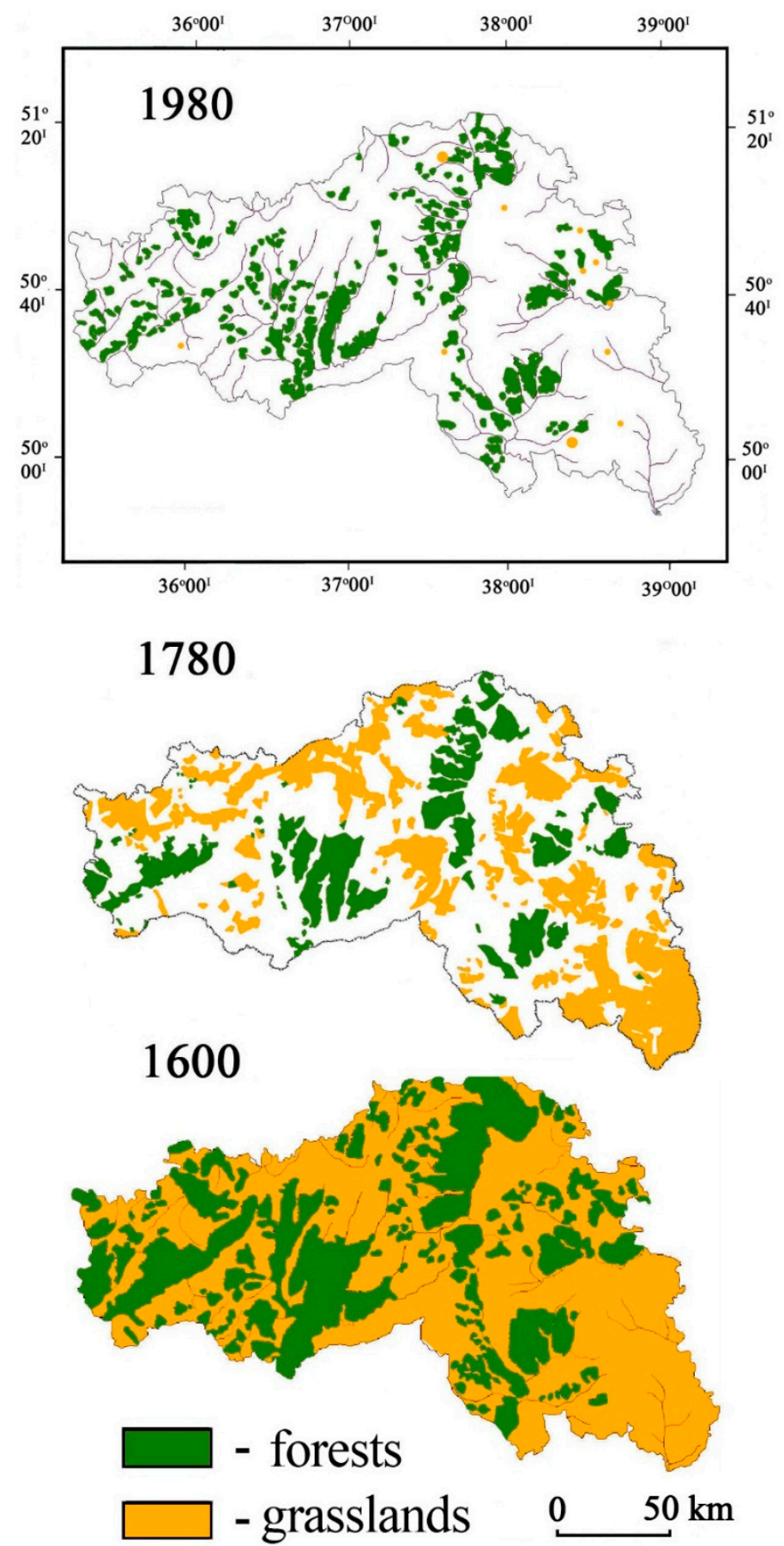

Figure 2. Distribution of forests and grasslands in the Belgorod Oblast in different historical periods (compiled from archival sources and literary and cartographic materials).

It is well known that forests have an important impact on the environment - they play a role in regulating surface runoff as well as form more wet/humid climatic conditions. Therefore, deforestation of Belgorod Oblast impacted the climate (which become drier), which may have also contributed to the further deterioration of soil quality and reduction of crop yields. 
Aside from deforestation, significant degradation of Chernozem soils has occurred due to long-term cultivation without or with sporadic replenishment of nutrients with fertilizers. According to Chendev and Petin [10], the mean duration of Chernozem soil cultivation in the Belgorod Oblast is approximately 240 years. Thus, at the beginning of the research by Dokuchaev for 1877-1879 [1], the soils had been already under agricultural management no less than 100 years. The lack of organic fertilizers (manure) in a large area of arable soils at the end of the 19th century (Figure 3) certainly influenced the appearance of an ecological crisis due to Chernozem soil nutrient depletion.

A

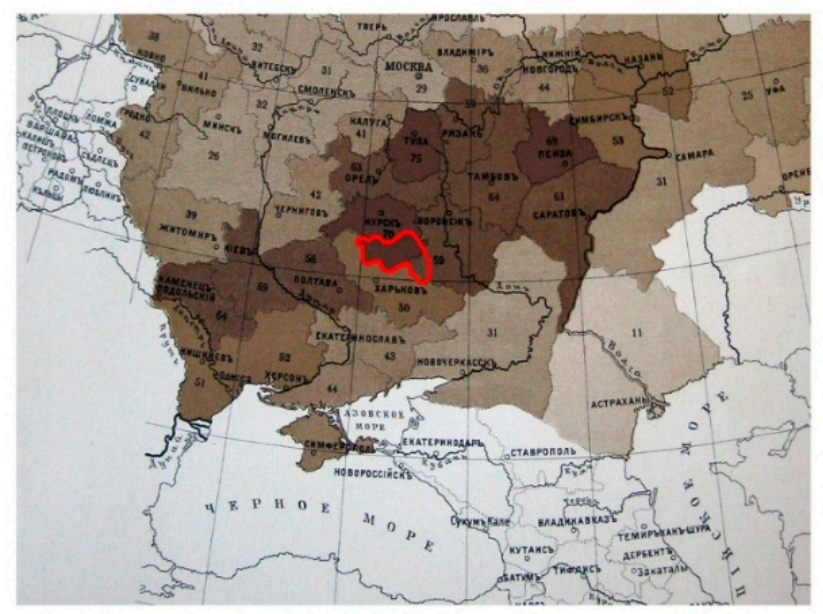

Distribution of arable lands, $\%$ at total area:

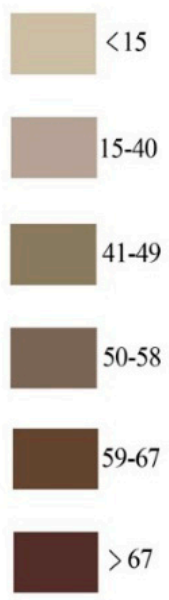

B

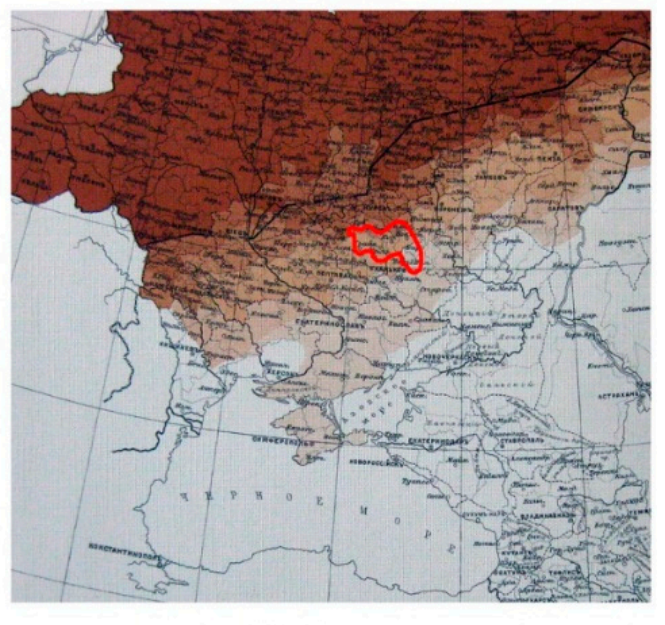

Use of manure :

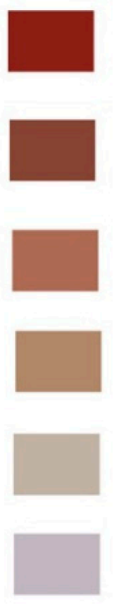

all large and majority of small land owners

majority of large and many small land owners

many large and some small land owners

some large and smal land owners

some large and nobody of small land owners

nobody of land owners

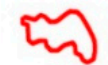

- contour of modern Belgorod oblast

Figure 3. Distribution of arable lands (A) and use of manure (B) in the Southern part of European Russia at the end of the 19th century (1887) [11].

The unfavorable state of agricultural land fertility was exacerbated by the natural relief with a large proportion of relatively steep slopes and by the practice of plowing along, not across, slopes. From year to year, plow furrows along slopes led to gully network formation. Realistic documentation of the 19th century cultivation practices were captured by artist's paintings demonstrating these phenomena (Figures 4 and 5). 


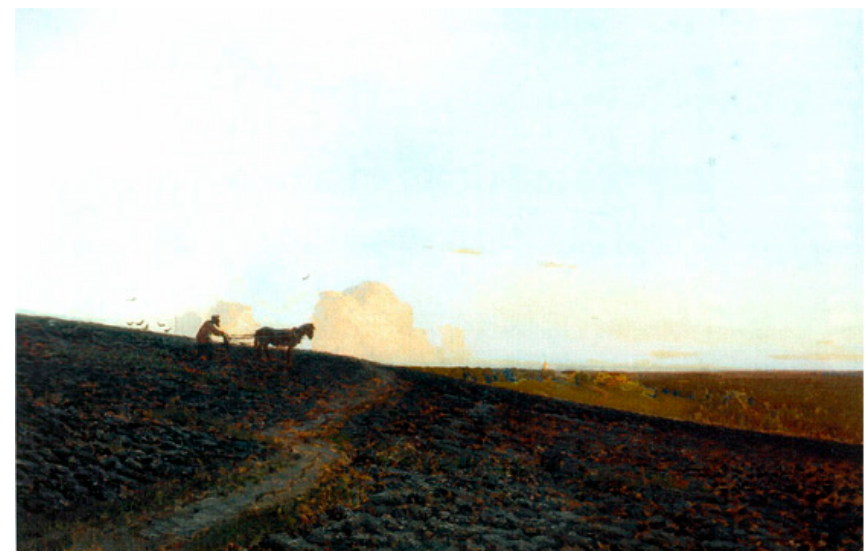

Figure 4. Painting of I. Levitan "The evening on arable land" (second half of the 19th century) (in the painting plowing along the slope is visible).

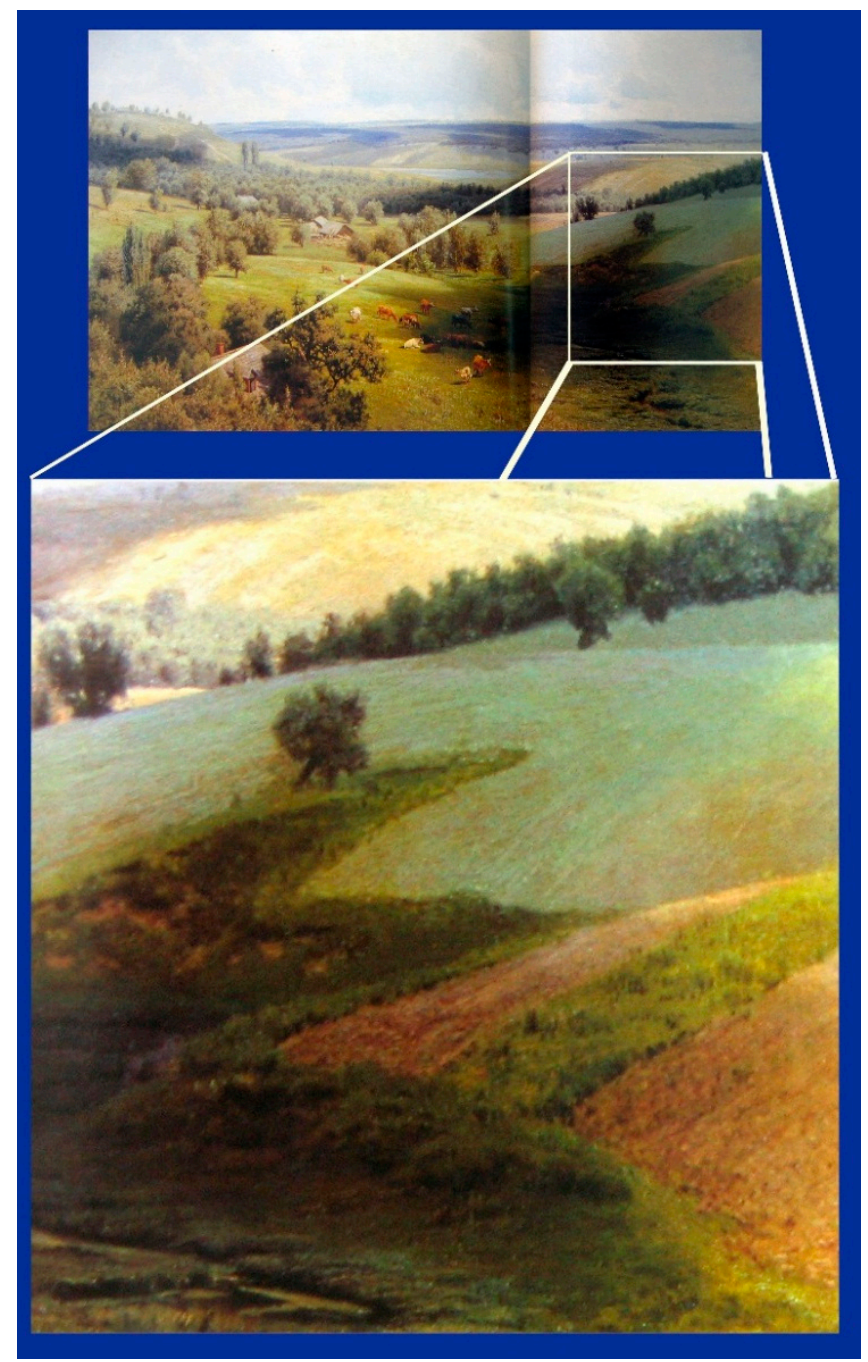

Figure 5. Painting of N. Sergeyev "Summer Landscape" (second half of the 19th century). In the enlarged fragment, plow furrows are visible along the slope, with the formation of a new, expanding gully downslope.

The sheet and rill water erosion of arable lands along with the practice of plowing along slopes led to the increase in the number of fields intersected by gullies (Figure 6). 


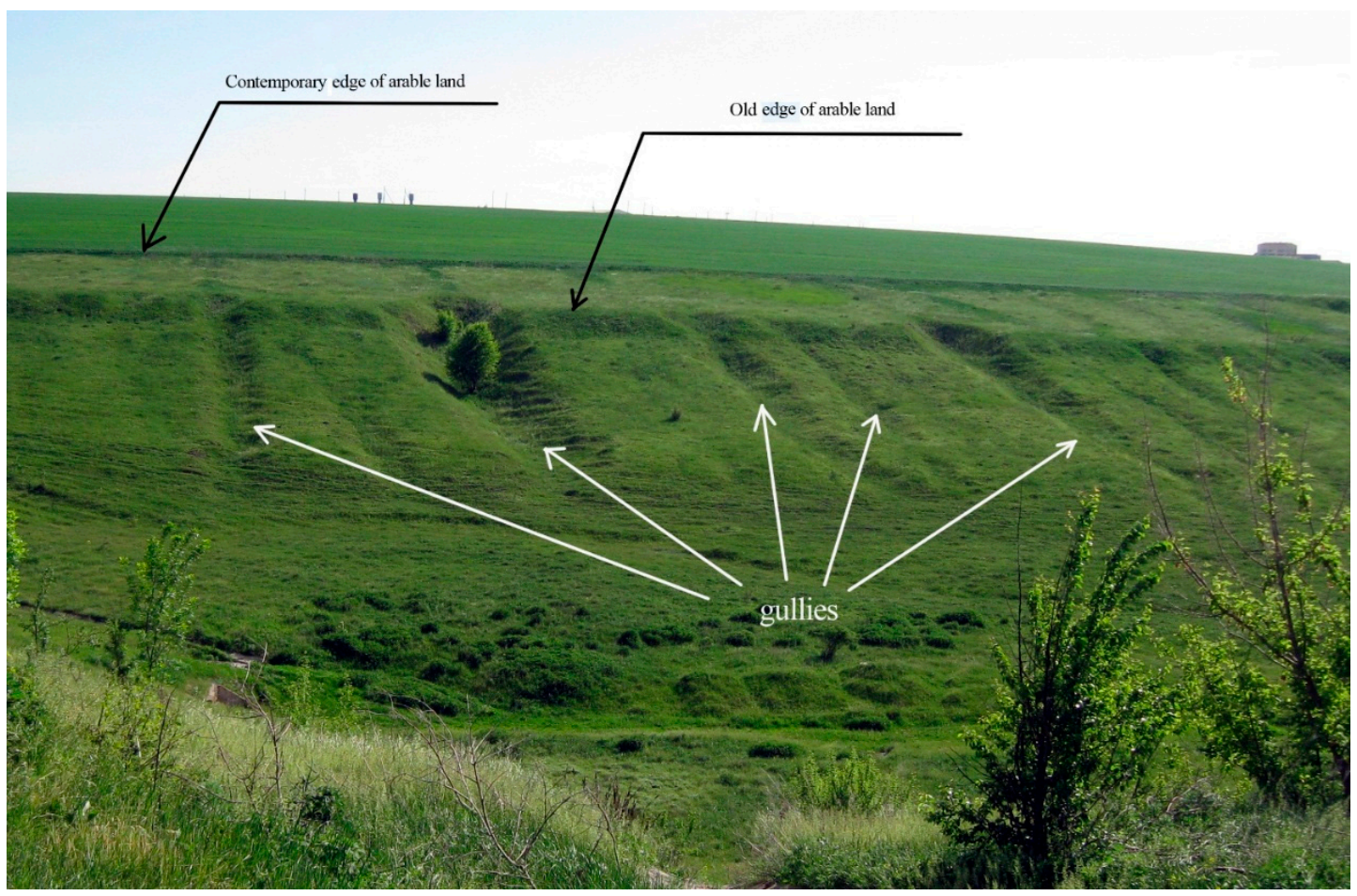

Figure 6. Slope of natural ravine with secondary forms of relief - earthen plowed rampart along old (beginning of 20th century) edge of arable land, and gullies associated with this edge. (Photo in Korocha district of Belgorod Oblast).

It is estimated that, for the history of agricultural management in the Belgorod Oblast, the average rate of gully network growth was equal to $56.5 \mathrm{~km} \cdot \mathrm{year}^{-1}$ and the annual loss of land by new gully formation was approximately $1.1 \mathrm{~km}^{2}$. The total volume of soil and rock eroded by gully formation over the history of land management in the study region was estimated to be $2-2.5 \mathrm{~km}^{3}$, which is equal to a 7-cm layer of soil with bulk density $1.15 \mathrm{~g} \cdot \mathrm{cm}^{-3}$ distributed over the entire area $\left(27,134 \mathrm{~km}^{2}\right)$ of Belgorod Oblast [10].

So, we see that many factors contributed to the depletion of Chernozem soils in the 19th-early 20th centuries. Separate consideration is given to historical changes in tillage technologies and their impact on soil fertility. According to an analysis of land use history in the study territory, soils before the 1930s were tilled with wooden and iron plows to a depth of 10-20 cm. Mechanical plowing with tractors led to a gradually increasing depth of the plow layer. At present, primary tillage penetrates to a depth of 30-37 cm. The wide using of mineral and organic fertilizers began only after World War II. However, volumes of fertilization were relatively low. The annual input of farmyard manure has never been higher than $4 \mathrm{Mg} \cdot \mathrm{ha}^{-1}$ — at least until the end of the 20 th century. Another factor is that, since the $1960 \mathrm{~s}$, more sugar beet and other industrial crops have been cultivated in addition to the cereal crops. These crops require higher use of farm machinery on fields. This led to further deterioration of arable Chernozems' physical properties through compaction and destruction of soil structure $[12,13]$.

Therefore, we conclude that cultivation practices for almost all of the history of agriculture did not favorably affect soil quality and soil fertility. An exception to this pattern has occurred only during the last few years in the Belgorod Oblast. Agricultural development with new land owners and agricultural holdings has begun to use advanced technologies of cultivation such as minimum and zero tillage. They 
use scientifically recommended rates of soil mineral and organic fertilizers. To protect soils on sloping lands from soil erosion, some cultivated fields have been sown to forage grasses. Soil conservation farming systems are being increasingly introduced in the practice of modern agriculture.

Tillage practices and other agricultural technologies during the historical changes of Chernozems in the Belgorod Oblast — like other regions of the Southern part of European Russia—which did not serve to improve soil quality. Many current practices add to this long (several centuries) agricultural management of these soils with an accumulation of negative effects on the current properties of these soils.

As has been shown above, V.V. Dokuchaev [2] founded a new science about soils, which today is known as soil science or pedology, based on the study of Russian Chernozems. The initial reason for their study by Dokuchaev was the Russian government's concern over the decrease in fertility of these soils. The initial focus of soil science after 1883 was to find ways to decrease the rate of Chernozem degradation as well as improve their condition and fertility. Again, Dokuchaev was the first scientist who drew attention to afforestation of agricultural lands within Chernozem area as the most effective measure for their protection and restoration [4]. Further agricultural land management practices in the Soviet Union (since the beginning of 1950s) through afforestation brought positive results until the end of the 20th century. However, afforestation of agricultural lands during the last two decades (since 1991) declined due to changes in the political and economic status of Russia. Many older windbreaks have been removed [5]. In spite of the introduction of new crop production technologies and tillage practices in recent years in Russia, significant rehabilitation of windbreaks has not occurred. There is a need to re-focus attention on soil rehabilitation, and special attention should be given to agroforestry practices as one of the most effective ways to improve, protect and rehabilitate Russian Chernozems.

Afforestation of steppe agricultural lands is a well-known practice and it has a long history of practice in cropland management not only in Russia, but within other regions of Northern Hemisphere [5,14,15]. In the 19th and 20th centuries, preferences for this practice were connected with protection of croplands from wind and water erosion, improvement of microclimate for crop growth, and creation of new refugia for wild animal and plant habitat. At the end of the 20th to the beginning of the 21 st centuries, windbreaks were often viewed from the ecosystem perspective for atmospheric carbon sequestration, having positive influence on the climatic balance of $\mathrm{CO}_{2}$ [16-19]. Therefore, the current objectives of this study are the collection and analysis of new data, reflecting opportunities for windbreaks to sequester soil organic carbon and rehabilitate degraded soils. One such perspective region, naturally presented by Chernozems, is the Central Russian Upland, situated within the central part of Eastern Europe.

\section{Materials and Methods}

This study focuses on Chernozems of the Central Russian Upland under different types of vegetation - virgin grasslands, crops, and windbreaks. For selection of the study key areas, the authors were guided by the following requirements: key areas must be situated in the forest-steppe zone (a transitional zone between forest and steppe); topographically they must be located on flat summits; and all key areas must be in close proximity to each other. Sub-areas under virgin vegetation, arable land, and a windbreak planted on formerly cultivated land were identified within the same kind of soil having homogeneous parent material. The location of the study key areas is shown in Figure 7. Historical stages of agricultural and agroforestry management of the study soils is illustrated in Figure 8. 


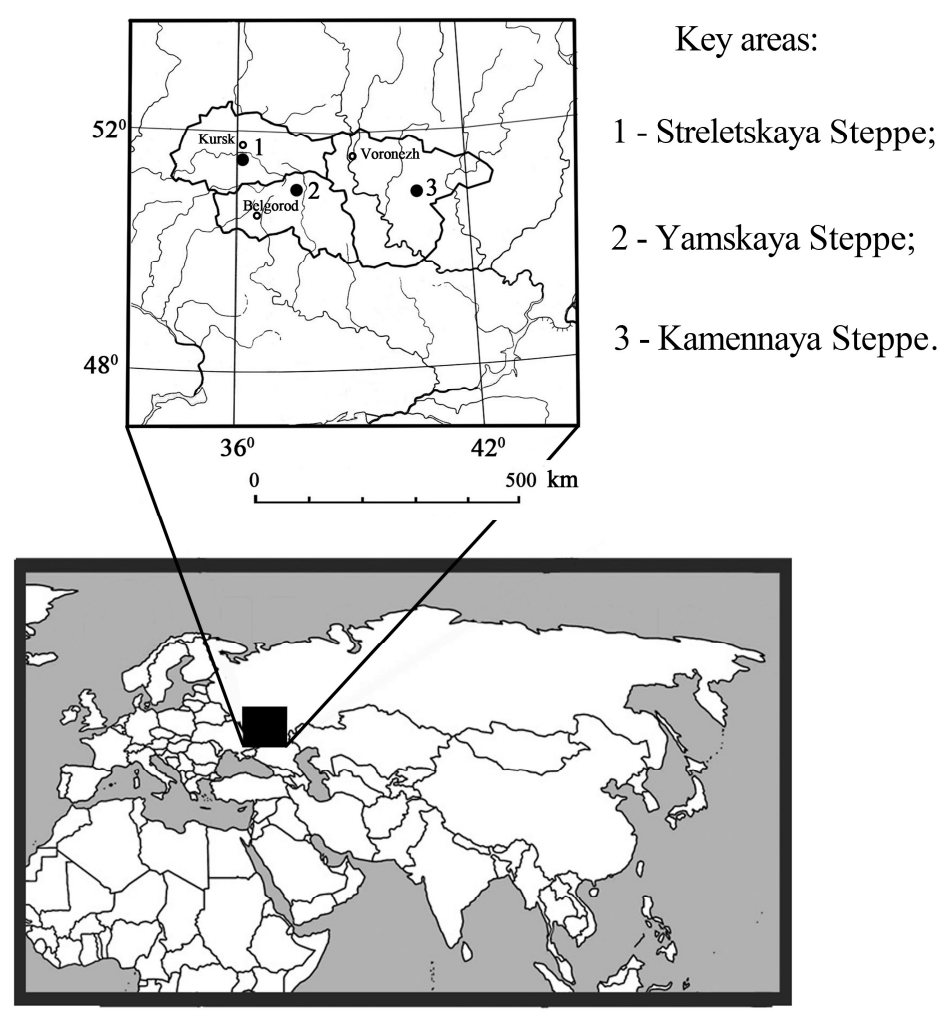

Figure 7. Locations of the study areas.

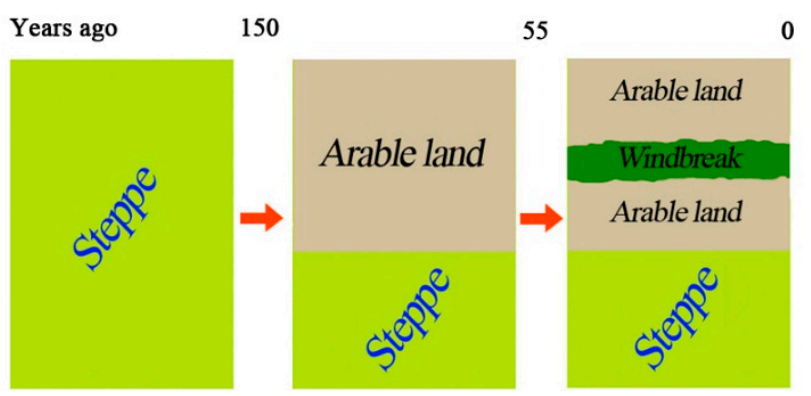

Figure 8. Historical changes of land management within the study areas in the Central Russian Upland.

Prior to undertaking field studies it was necessary to carefully select the key areas. This work included analysis of maps of different ages, selection and study of remote sensing data, and consultations with experts in the fields of geography, geobotany, and agroforestry. Reconnaissance visits to prospective areas of planned field research were also completed. The Central Russian Upland is an agricultural region (arable lands currently occupy about $60 \%$ of the total area); thus, it was challenging to find native grasslands in many places within the study area. Therefore, as a base, we selected sites located in the immediate vicinity of three State steppe preserves: near the Central Chernozem Preserve (key area Streletskaya Steppe, Kursk Oblast), in vicinity and on the territory of preserve "Belogorye" (key area Yamskaya Steppe, Belgorod Oblast), and in the preserve "Kamennaya Steppe" (key area Kamennaya Steppe, Voronezh Oblast). Information about elevation, parent materials, and classification status of the studied soils and some climatic indicators of the key areas are given in Table 1. An overview of the virgin Chernozem profiles, in particular thickness of their humus horizons, are shown in Figure 9. 
Table 1. Some natural indicators of the key areas studied in the Central Russian Upland.

\begin{tabular}{rccccccc}
\hline \multirow{2}{*}{$\begin{array}{c}\text { Topographic } \\
\text { Structure }\end{array}$} & $\begin{array}{c}\text { Name of Key } \\
\text { Area }\end{array}$ & $\begin{array}{c}\text { Elevation } \\
\text { above Sea } \\
\text { Level, } \mathbf{m}\end{array}$ & $\begin{array}{c}\text { Parent } \\
\text { Materials }\end{array}$ & Soils & $\begin{array}{c}\text { Annual } \\
\text { Precipitation, Temperature, } \\
\mathbf{m m}\end{array}$ & $\begin{array}{c}\text { Annual Mean } \\
{ }^{\mathbf{C}} \mathbf{C}\end{array}$ & HTC \\
\hline \multirow{2}{*}{$\begin{array}{c}\text { Sentral } \\
\text { Russian } \\
\text { Upland }\end{array}$} & $\begin{array}{c}\text { Streletskaya } \\
\text { Steppe }\end{array}$ & 240 & 1 & Leached Chernozems & 580 & +5.3 & 1.23 \\
\cline { 2 - 8 } & $\begin{array}{c}\text { Yamskaya } \\
\text { Steppe }\end{array}$ & 230 & 1 & Typical Chernozems & 530 & +5.6 & 1.1 \\
\cline { 2 - 8 } & $\begin{array}{c}\text { Kamennaya } \\
\text { Steppe }\end{array}$ & 190 & 2 & $\begin{array}{c}\text { Ordinary } \\
\text { Chernozems, } \\
\text { transitional to typical }\end{array}$ & 480 & +5.8 & 1.0 \\
\hline
\end{tabular}

Parent materials: 1 -loess carbonated loams; 2-loess carbonated clays. HTC-Hydrothermal Coefficient, $10 \mathrm{R} / \Sigma \mathrm{t}$, where $\mathrm{R}$ - precipitation in millimeters for the period with temperatures above $10^{\circ} \mathrm{C}, \Sigma \mathrm{t}-\mathrm{the}$ sum of temperatures in degrees Celsius for the same period [20].

Croplands of the study areas are either located in research sites (in Yamskaya Steppe and Kamennaya Steppe) or they are in farm use (Streletskaya Steppe). Age of cultivation after transfer of virgin grassland to arable land at all sites is approximately the same and estimated at 150 years. All key areas are using crop rotations with predominance of cereals, but in more cool and wet climatic conditions, (in areas Streletskaya Steppe and Yamskaya Steppe) crop rotations have increased proportions of fodder and sugar beet, and in the more drier climatic conditions (Kamennaya Steppe), increased proportions of cereals and sunflower.

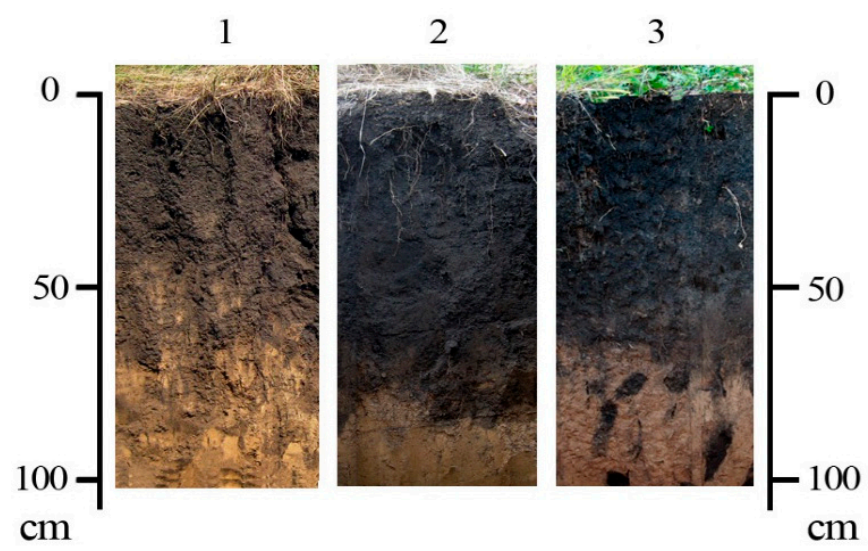

Figure 9. The profiles of virgin Chernozems of the study areas within the Central Russian Upland: 1-Streletskaya Steppe; 2-Yamskaya Steppe; 3-Kamennaya Steppe.

In all key areas, the windbreaks have multi-rows and a full/dense design. Their width varies from 20 (Streletskaya Steppe) to $35 \mathrm{~m}$ (Yamskaya Steppe) with intermediate width at Kamennaya Steppe of $25 \mathrm{~m}$. Shelterbelts were created in the middle to second half of the 1950s, and are 55-57 years old. The dominant trees are at Streletskaya Steppe-Black poplar (Populus nigra) and Silver birch (Betula pendula); at Yamskaya Steppe-Box elder (Acer negundo); and at Kamennaya Steppe_English oak (Quercus robur) and Balsam poplar (Populus balsamifera).

In spite of the desire to find homogeneous soil cover within each key area, we have not completely escaped its natural heterogeneity. Therefore, the study sub-areas in every key area are characterized by 
certain differences of soil, and therefore could not be considered as a single statistical sample. However, detection of general trends in soil properties (in particular, the thickness of humus profiles, content and stocks of organic carbon) under the windbreaks compared to arable lands on different sites suggests a certain direction of windbreak effects on soil organic matter.

Studies in all key areas were carried out using consistent methodology. Soil samples were collected along three equally spaced $(5 \mathrm{~m})$ transects across the windbreak including arable lands on both sides at spacings of 4-5 $\mathrm{m}$. Soil was sampled to $30 \mathrm{~cm}$ at every point in triplicate followed by compositing into one sample. The total number of points along each transect was equal to 18 , six of which were under the windbreak, and four from both sides of the neighboring arable lands. With three transects within every key area, the total numbers of samples were: 18 - under windbreak, and on 12 in every sub-area of arable land. Based on the variation of windbreak width (20-35 m), total area of sampling under tree plantations varied from 200-350 $\mathrm{m}^{2}$ (band with 10-m width), and in arable lands on both sides of plantations - 120-150 $\mathrm{m}^{2}$ (also in form of a band with 10-m width).

This technique of soil sampling with subsequent statistical analysis of results is widely used in the study of soils in agroforestry areas in the United States [18].

Additionally, in each sub-area, a large soil pit was prepared by hand to a depth of $1.5 \mathrm{~m}$. All soil horizon boundaries and profile descriptions were prepared from observations of three exposed soil faces. Horizon boundaries were measured at five locations on each exposed face. Sampling of soils in every soil pit was executed to a depth of $1 \mathrm{~m}$ in two opposite soil faces with following meaning of laboratory analysis results. Soil pits were located in central parts of the windbreaks, and in the fields on both sides of the windbreaks adjacent to of the soil sampling transects at the greatest distance from the edge of windbreak. Distance between soil pits on arable lands and under windbreaks varied depending of windbreak width from $25-35 \mathrm{~m}$. Soils of virgin sub-areas were studied in large pits and with a series of auxiliary deep soil cores.

Thus, within every key area 48 soil samples to depth $0-30 \mathrm{~cm}$ and double selections from four soil pits in every $10 \mathrm{~cm}$ to depth $1 \mathrm{~m}$ were collected for a total of 80 soil samples. After drying, preparation of soil samples for laboratory analyses was executed according to standard methods. Soil samples were analyzed to determine soil organic carbon (SOC) content and bulk density (for the following recalculation of SOC content into soil carbon stocks). Sampling for bulk density in pits at selected points in the profile were collected with steel rings.

The SOC content was determined by dry combustion analysis NA 15000 Fison (ThermoQuest Corp., Austin, TX, USA) at the National Laboratory for Agriculture and the Environment of USDA (Ames, IA, USA). Visible roots were removed and a subsample passed through a $2 \mathrm{~mm}$ sieve, air dried, and roller-milled before SOC content analysis. Results are presented for the means of pit and point samples.

In statistical analysis of data in Tables 2 and 3, a 95\% confidence level ( $p=0.05$ ) was used.

\section{Results}

An important morphogenetic indicator characterizing the direction of change with time of the studied soils transition from "grassland-arable land-windbreak", are the thickness of their humus horizons (A) and humus profiles ( $+\mathrm{AB}$ horizons) (Table 2). For the three study key areas, humus horizon thickness of virgin Chernozems varied from $44.7-52.9 \mathrm{~cm}$, and their humus profiles - from $70.3-75.5 \mathrm{~cm}$. 
After 55-57 years of soil formation of Chernozems under windbreaks, the thickness of their humus horizon relevant to background (virgin) analogues (at Streletskaya Steppe), were significantly higher than background (at Yamskaya Steppe — by $7 \mathrm{~cm}$, and at Kamennaya Steppe—by $5 \mathrm{~cm}$ ). In Chernozems under windbreaks, humus profile thickness is significantly higher than in virgin grasslands (in Streletskaya Steppe - by $11 \mathrm{~cm}$, in Yamskaya Steppe - by $5 \mathrm{~cm}$ ). This index is significantly lower in the area Kamennaya Steppe $-9 \mathrm{~cm}$, by comparison with the windbreak's Chernozem. At each location, there were significantly greater thicknesses of the $A+A B$ horizons in soils beneath tree plantings compared to the adjacent cultivated soils. The difference in $\mathrm{A}+\mathrm{AB}$ thickness between tree and crop soils was 18.3, 10.9, and $5.6 \mathrm{~cm}$ for the Streletskaya Steppe, Yamskaya Steppe, and Kamennaya Steppe locations, respectively (Table 2). It is likely that these differences in thickness of the $\mathrm{A}+\mathrm{AB}$ horizons are due to both continued SOC loss from cropping practices, especially tillage, and SOC accumulation beneath the trees where there is both greater biomass input and limited soil disturbance.

Table 2. Statistics of humus horizons and humus profiles thickness of soils within three study areas in the Central Russian Upland.

\begin{tabular}{|c|c|c|c|c|c|c|}
\hline Sub-Area & Horizon/s & $\mathbf{n}$ & $\begin{array}{c}\text { Min-Max, } \\
\mathbf{c m} \\
\end{array}$ & $\mathbf{X} \pm \delta_{\mathbf{X}}, \mathbf{c m}$ & $\delta, \mathrm{cm}$ & $\mathrm{V}, \%$ \\
\hline \multicolumn{7}{|c|}{ Streletskaya Steppe, Kursk Oblast } \\
\hline \multirow{2}{*}{ Grassland } & $\mathrm{A}$ & 15 & $40-54$ & $44.7 \pm 0.9$ & 3.30 & 7.4 \\
\hline & $\mathrm{A}+\mathrm{AB}$ & 15 & $60-77$ & $70.3 \pm 1.0$ & 3.87 & 5.5 \\
\hline \multirow{2}{*}{ Windbreak } & $\mathrm{A}$ & 15 & $35-50$ & $44.6 \pm 1.3$ & 5.19 & 11.6 \\
\hline & $\mathrm{A}+\mathrm{AB}$ & 15 & $75-85$ & $81.4 \pm 1.0$ & 3.80 & 4.7 \\
\hline \multirow{2}{*}{ Cultivated land } & $\mathrm{Ap}+\mathrm{A}$ & 30 & $33-48$ & $37.3 \pm 0.6$ & 3.48 & 9.3 \\
\hline & $\mathrm{Ap}+\mathrm{A}+\mathrm{AB}$ & 30 & $47-80$ & $63.1 \pm 2.0$ & 10.83 & 17.2 \\
\hline \multicolumn{7}{|c|}{ Yamskaya Steppe, Belgorod Oblast } \\
\hline \multirow{2}{*}{ Grassland } & A & 15 & $47-58$ & $52.9 \pm 0.9$ & 3.45 & 6.5 \\
\hline & $\mathrm{A}+\mathrm{AB}$ & 15 & $69-80$ & $75.5 \pm 0.9$ & 3.36 & 4.5 \\
\hline \multirow{2}{*}{ Windbreak } & $\mathrm{A}$ & 15 & $46-64$ & $60.1 \pm 1.9$ & 7.31 & 12.2 \\
\hline & $\mathrm{A}+\mathrm{AB}$ & 15 & $71-92$ & $80.1 \pm 1.6$ & 6.29 & 7.9 \\
\hline \multirow{2}{*}{ Cultivated land } & $\mathrm{Ap}+\mathrm{A}$ & 30 & $39-56$ & $45.3 \pm 0.9$ & 4.65 & 10.3 \\
\hline & $\mathrm{Ap}+\mathrm{A}+\mathrm{AB}$ & 30 & $54-82$ & $69.2 \pm 1.3$ & 6.87 & 9.9 \\
\hline \multicolumn{7}{|c|}{ Kamennaya Steppe, Voronezh Oblast } \\
\hline \multirow{2}{*}{ Grassland } & A & 15 & $41-55$ & $44.7 \pm 0.9$ & 3.56 & 8.0 \\
\hline & $\mathrm{A}+\mathrm{AB}$ & 15 & $69-88$ & $75.5 \pm 1.3$ & 4.91 & 6.5 \\
\hline \multirow{2}{*}{ Windbreak } & $\mathrm{A}$ & 15 & $46-55$ & $49.6 \pm 0.8$ & 3.09 & 6.2 \\
\hline & $\mathrm{A}+\mathrm{AB}$ & 15 & $57-70$ & $64.1 \pm 1.0$ & 3.80 & 5.9 \\
\hline \multirow{2}{*}{ Cultivated land } & $A p+A$ & 30 & $37-47$ & $41.0 \pm 0.4$ & 2.37 & 5.8 \\
\hline & $\mathrm{Ap}+\mathrm{A}+\mathrm{AB}$ & 30 & $49-64$ & $58.5 \pm 0.6$ & 3.52 & 6.0 \\
\hline
\end{tabular}

A plot of the difference of $\mathrm{A}+\mathrm{AB}$ horizon thickness of tree and grass soils $v s$. HTC for the three studied sites exhibits a linear dependence (Figure 10).

In accordance with the observed trend (Figure 10), the humus profile thickness in soils under artificial forest plantations increased by $10 \mathrm{~cm}$ for every 0.1 unit increase in HTC. For the area of 
the Central Russian Upland, this corresponds to an advance in a northwesterly direction of a distance of 30-70 (average 50) km.

Statistical analysis of SOC stock distribution in the $0-30 \mathrm{~cm}$ of study soils (Table 3 ) shows an increase of this index in native grasslands from the cool-wet part of Central Russian Upland to its warm-dry locations. In leached Chernozems of Streletskaya Steppe they are $126.2 \pm 2.3 \mathrm{Mg} \cdot \mathrm{ha}^{-1}$, in typical Chernozems of Yamskaya Steppe-138.0 $\pm 3.9 \mathrm{Mg} \cdot \mathrm{ha}^{-1}$, and in ordinary Chernozems of Kamennaya Steppe-152.5 $\pm 4.7 \mathrm{Mg} \cdot \mathrm{ha}^{-1}$. Spatial variation of SOC stocks in virgin soils in this direction also increase with coefficients of variation of 4.4, 6.8 and 7.5, respectively (Table 3). In the areas Streletskaya Steppe and Yamskaya Steppe, no significant differences between virgin Chernozems and their windbreaks analogues on SOC stocks were determined. In these sites, arable soils were significantly lower on this index than soils of grasslands or windbreaks. At Kamennaya Steppe, SOC stocks in soils under the windbreak were about the same as in arable lands $-125.0 \pm 3.3 \mathrm{Mg} \cdot \mathrm{ha}^{-1}$ (on arable lands $-123.6 \pm 2.2 \mathrm{Mg} \cdot \mathrm{ha}^{-1}$ ) and significantly lower than in virgin Chernozems $-152.5 \pm 4.7 \mathrm{Mg} \cdot \mathrm{ha}^{-1}$ (Table 3).

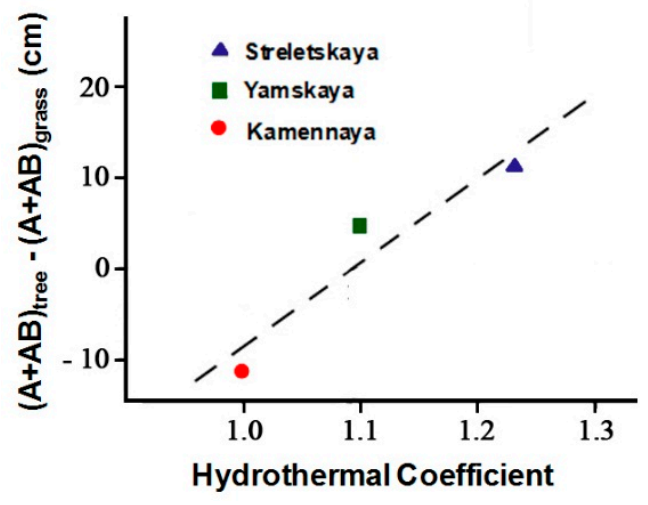

Figure 10. Difference of humus profile thickness in soils under tree plantings and uncultivated grassland soils vs. hydrothermal coefficient (HTC) within the Central Russian Upland.

Thus, we conclude that under windbreaks in more cooler and humid climatic conditions of the northern and central forest-steppe of the Central Russian Upland (Streletskaya Steppe and Yamskaya Steppe), an increase of humus reserve by decay of ground litter and roots under windbreaks is obvious in the $0-30 \mathrm{~cm}$ layer of Chernozems, while in more dry and warm south-east conditions of the study region, this process is manifested more weakly.

Characteristics of individual soil profiles on SOC stocks to a depth of $100 \mathrm{~cm}$, which have been studied in three sub-areas within every key site, are presented in Table 4. As in the 0-30 cm layer (Table 3), in the layers of 0-50, 50-100 and 0-100 cm, SOC stocks of virgin Chernozems regularly decrease from cool-wet to warm-dry forest-steppe of the Central Russian Upland (Table 4). The 0-50 cm layer of virgin Chernozems contains $66 \%-72 \%$ of the SOC in the surface meter of the soils. In Chernozems under windbreaks, there has been some vertical redistribution of SOC. In the $0-50 \mathrm{~cm}$ layer, SOC stocks have decreased to $59 \%-63 \%$ of its total stocks in the meter layer of soils due to replenishment of the organic carbon pool in the 50-100 cm layer. In the adjacent croplands, SOC stocks also decreased in the $0-50 \mathrm{~cm}$ layer to $60 \%-67 \%$ of the total stocks in the $0-100 \mathrm{~cm}$ layer (Table 4). 
However, the cause of this decline is likely associated with more intensive decomposition of organic matter in the upper soil layers as a result of continued cultivation.

Table 3. Statistic indexes of spatial distribution of SOC stocks $\left(\mathrm{Mg} \cdot \mathrm{ha}^{-1}\right)$ in study soils, layer 0-30 cm (Central Russian Upland).

\begin{tabular}{|c|c|c|c|c|c|}
\hline Sub-Area & $\mathbf{n}$ & Min-Max & $\mathbf{X} \pm \boldsymbol{\delta}_{\mathbf{X}}$ & $\boldsymbol{\delta}$ & $\mathrm{V}, \%$ \\
\hline \multicolumn{6}{|c|}{ Streletskaya Steppe } \\
\hline Grassland & 6 & $119.9-135.4$ & $126.2 \pm 2.3$ & 5.55 & 4.4 \\
\hline Windbreak & 18 & $109.9-241.1$ & $126.4 \pm 7.0$ & 29.74 & 23.5 \\
\hline Cultivated land & 24 & $91.5-126.7$ & $109.3 \pm 2.1$ & 10.24 & 9.4 \\
\hline \multicolumn{6}{|c|}{ Windbreak-Grassland $=+0.2 ;$ LSD $_{05}=15.2$} \\
\hline \multicolumn{6}{|c|}{ Windbreak - Cultivated land $=+17.1 ; \mathrm{LSD}_{05}=14.7$} \\
\hline \multicolumn{6}{|c|}{ Yamskaya Steppe } \\
\hline Grassland & 6 & $131.2-155.9$ & $138.0 \pm 3.9$ & 9.44 & 6.8 \\
\hline Windbreak & 18 & $119.3-163.2$ & $142.1 \pm 3.0$ & 12.81 & 9.0 \\
\hline Cultivated land & 24 & $111.2-156.8$ & $127.2 \pm 2.4$ & 11.80 & 9.3 \\
\hline \multicolumn{6}{|c|}{ Windbreak-Grassland $=+4.1 ;$ LSD $_{05}=10.1$} \\
\hline \multicolumn{6}{|c|}{ Windbreak-Cultivated land $=+14.9 ; \mathrm{LSD}_{05}=7.7$} \\
\hline \multicolumn{6}{|c|}{ Kamennaya Steppe } \\
\hline Grassland & 6 & $135.9-170.0$ & $152.5 \pm 4.7$ & 11.40 & 7.5 \\
\hline Windbreak & 18 & $104.4-156.5$ & $125.0 \pm 3.3$ & 14.10 & 11.3 \\
\hline Cultivated land & 24 & $100.0-140.7$ & $123.6 \pm 2.2$ & 10.98 & 8.9 \\
\hline \multicolumn{6}{|c|}{ Windbreak-Grassland $=-27.5 ;$ LSD $_{05}=11.8$} \\
\hline \multicolumn{6}{|c|}{ Windbreak-Cultivated land $=+1.4 ; \mathrm{LSD}_{05}=8.1$} \\
\hline
\end{tabular}

Note: $\mathrm{LSD}_{05}$ - Least significant difference at $95 \%$ confidence level.

Table 4. SOC stocks in study soil profiles under virgin grasslands, windbreaks, and adjacent to the windbreaks crop fields within the Central Russian Upland.

\begin{tabular}{|c|c|c|c|c|c|c|}
\hline \multirow[b]{3}{*}{ Layer, cm } & \multicolumn{6}{|c|}{ Key Site } \\
\hline & \multicolumn{2}{|c|}{ Streletskaya Steppe } & \multicolumn{2}{|c|}{ Yamskaya Steppe } & \multicolumn{2}{|c|}{ Kamennaya Steppe } \\
\hline & $\begin{array}{c}\text { SOC Stocks, } \\
\mathbf{M g} \cdot \mathbf{h a}^{-1}\end{array}$ & $\begin{array}{c}\% \text { of Stocks in } \\
\text { Layer } \\
0-100 \mathrm{~cm}\end{array}$ & 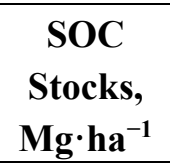 & $\begin{array}{c}\% \text { of Stocks in } \\
\text { Layer } \\
0-100 \mathrm{~cm}\end{array}$ & $\begin{array}{c}\text { SOC } \\
\text { Stocks, } \\
\mathbf{M g} \cdot \mathbf{h a}^{-1}\end{array}$ & $\begin{array}{c}\% \text { of Stocks } \\
\text { in Layer } \\
0-100 \mathrm{~cm} \\
\end{array}$ \\
\hline \multicolumn{7}{|c|}{ Grasslands } \\
\hline $0-50$ & 175.0 & 72 & 208.2 & 66 & 227.9 & 67 \\
\hline $50-100$ & 68.5 & 28 & 105.7 & 34 & 113.6 & 33 \\
\hline $0-100$ & 243.5 & 100 & 313.9 & 100 & 341.5 & 100 \\
\hline \multicolumn{7}{|c|}{ Windbreaks } \\
\hline $0-50$ & 178.6 & 63 & 237.3 & 63 & 208.6 & 59 \\
\hline $50-100$ & 104.6 & 37 & 139.7 & 37 & 147.3 & 41 \\
\hline $0-100$ & 283.2 & 100 & 377.0 & 100 & 355.9 & 100 \\
\hline \multicolumn{7}{|c|}{ Cultivated lands near windbreaks (mean on 2 profiles) } \\
\hline $0-50$ & 188.5 & 67 & 186.6 & 60 & 189.9 & 67 \\
\hline $50-100$ & 93.8 & 33 & 126.2 & 40 & 95.3 & 33 \\
\hline $0-100$ & 282.4 & 100 & 312.8 & 100 & 285.2 & 100 \\
\hline
\end{tabular}


The vertical redistribution of SOC in soils beneath windbreaks cannot be explained by these soils having such profiles from their arable period before afforestation since the growth of relative stocks of SOC in the 50-100 cm layer beneath the tree plantations has been identified together with an excess of their absolute values in comparison with the same layers of the virgin Chernozems (Table 4, Figure 11).

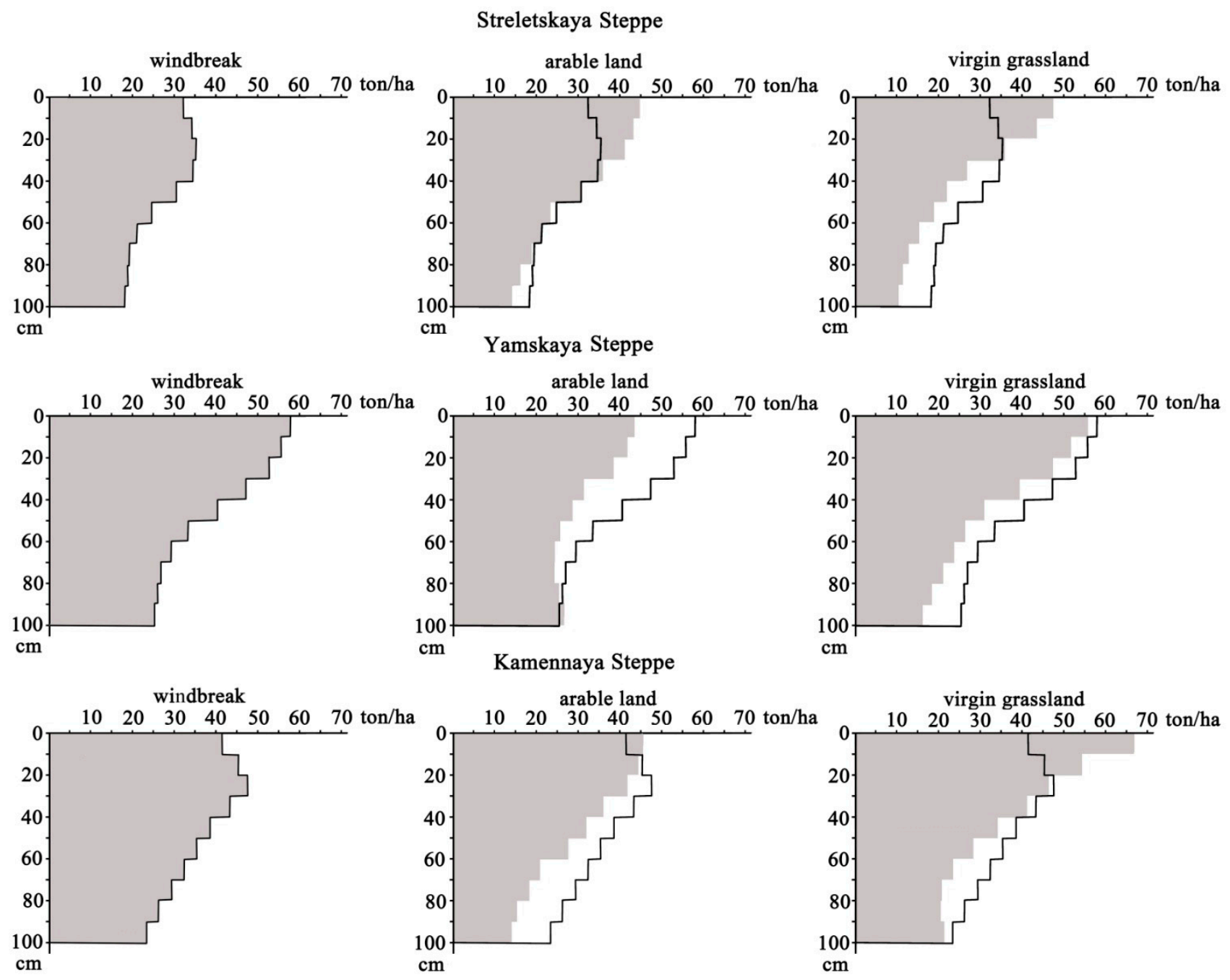

Figure 11. Vertical distribution of SOC stocks in profiles of study soils within the Central Russian Upland. In diagrams, reflecting arable and virgin Chernozems, the profile for soils beneath windbreaks is shown for comparison. Reproduced from [21].

Also, we identified reliable differences in SOC stocks between windbreaks and grasslands, and between windbreaks and cultivated lands within the 50-100 cm layer as average indexes for all key plots (Table 5). This may serve as further evidence of SOC stock accumulation in Chernozems under windbreaks, the result of windbreak influence on soils.

Thus, according to our study, we confirm that 55 year-old windbreaks within the Central Russian Upland forest-Steppe lead to improvement in the quality of Chernozem soils by addition of SOC. This finding is supported by similar studies in other geographic regions, however, not all afforestation projects yield such positive results. Studies from past plantings may also have produced different results than plantings today may produce in the future under potentially different climate conditions. At present, opinions of different authors vary: some of them detected increases of SOC under windbreaks of Europe 
and the USA $[16,18,22,23]$; others found changes in comparison of these soils with the initial SOC state of virgin grasslands soils $[4,24,25]$. A further complication is the change in SOC, and other properties under windbreaks vary with time. For example, a study of windbreaks of different ages in the state of Iowa in the USA found varying responses in Mollisols to sequestration of organic carbon with a tendency of this process slowing 30 years after windbreak planting [26].

Table 5. Average SOC stocks $\left(\mathrm{Mg} \cdot \mathrm{ha}^{-1}\right)$ in soils under virgin grasslands, windbreaks, and crop fields adjacent to the windbreaks on three study areas (Streletskaya, Yamskaya, Kamennaya Steppe), Central Russian Upland.

\begin{tabular}{cccc}
\hline \multirow{2}{*}{ Sub-Area } & \multicolumn{3}{c}{ Layer, $\mathbf{c m}$} \\
\cline { 2 - 4 } & $\mathbf{0 - 5 0}$ & $\mathbf{5 0 - 1 0 0}$ & $\mathbf{0 - 1 0 0}$ \\
\hline Windbreaks, $n=6$ & $208 \pm 11$ & $131 \pm 8$ & $339 \pm 18$ \\
\hline Grasslands, $n=6$ & $204 \pm 10$ & $96 \pm 9$ & $300 \pm 18$ \\
\hline Cultivated lands, $n=6$ & $188 \pm 1$ & $105 \pm 7$ & $293 \pm 6$ \\
\hline Windbreaks-Grasslands & $\frac{+4}{33}$ & $\frac{+35}{30}$ & $\frac{+39}{57}$ \\
\hline LSD & $\frac{+20}{25}$ & $\frac{+26}{24}$ & $\frac{+46}{45}$ \\
\hline Windbreaks-Cultivated lands & & &
\end{tabular}

\section{Conclusions}

Chernozems of the Central Russian Upland respond rapidly to anthropogenic influences in the form of plowing and afforestation of agricultural lands. Tree cover improves soil quality by increasing A and $\mathrm{A}+\mathrm{AB}$ horizon thickness and total SOC stocks. Maximum effect of this favorable soil development was found in relatively cooler and wetter conditions of central and north-western forest-steppe (Streletskaya Steppe and Yamskaya Steppe).

Depth of the SOC-enriched surface horizon was strongly correlated with a climate index, the HTC. A $10 \mathrm{~cm}$ growth of humus profile thickness in soils under windbreaks was observed for every HTC increase by 0.1 . For the Central Russian Upland, this corresponds to an advance in a northwesterly direction of $50 \mathrm{~km}$. In every key site, an increase in soil organic carbon stocks in the $0-100 \mathrm{~cm}$ layer of afforested (beneath windbreaks) Chernozems was greater than in the virgin grassland Chernozems. More significant change was especially evident in the 30-100 cm layer: at Streletskaya Steppe- $40 \mathrm{Mg} \cdot \mathrm{ha}^{-1}$, at Yamskaya Steppe $-59 \mathrm{Mg} \cdot \mathrm{ha}^{-1}$, and at Kamennaya Steppe $-42 \mathrm{Mg} \cdot \mathrm{ha}^{-1}$.

Afforestation in the form of field windbreaks is an effective means to increase $\mathrm{C}$ storage, restore soil fertility by improving nutrient cycling and availability, protect Chernozem soils from water and wind erosion, and produce high and stable crop yields in southern European Russia. Regarding the problem of global climate change, sequestration of atmospheric carbon into tree phytomass and organic matter of soils of the windbreak ecosystems can be seen as a positive effect in the biosphere. Agroforestry management, which had a high significance in the Soviet Union (period from 1948-1960s, during rapid economic growth and industrial reconstruction, needs to continue and expand across agricultural lands today and in the future. 


\section{Acknowledgments}

The authors are grateful for the assistance of Aleksandr Petin, Larisa Novykh, Eugeny Zazdravnykh (Belgorod State University), Andry Dolgikh (Institute of Geography, Russian Academy of Science, Moscow), Aleksandr Shapovalov (Reserve "Belogorye"), Yury Cheverdin and Valerian Tischenko (Reserve "Kamennaya Steppe").

\section{Author Contributions}

Yury G. Chendev supervised all preliminary and field studies in the key sites, analyzed results of field and laboratory data reported in this paper, performed literary review and drafted the paper's text. Thomas J. Sauer participated in field studies in all key sites and supervised laboratory analyses of soil properties reported herein. Both Yury G. Chendev and Thomas J. Sauer have been Principal Investigators of a CRDF project RUG1-7024-BL-11, thematically connected to this paper. Thomas J. Sauer served as secondary author, providing significant input on all drafts. Guillermo Hernandez Ramirez, and Charles Lee Burras helped in analysis of all collected field data, took significant participation in discussions of the results, performed literary review and prepared some parts of the manuscript.

\section{Conflicts of Interest}

The authors declare no conflict of interest.

\section{References}

1. Dokychaev, V.V. Russian Chernozem; Printing house of Dekleron and Evdokimov: Saint Petersburg, Russian, 1883; p. 376. (In Russian)

2. Gennadiev, A.N.; Glazovskaya, M.A. Geography of Soils with Foundations of Soil Science; Moscow State University Press: Moscow, Russian, 2005; p. 461. (In Russian)

3. Ivanov, I.V. History of Russian Pedology; Nauka: Moscow, Russian, 2003; p. 397. (In Russian)

4. Mil'kov, F.N.; Nesterov, A.I.; Petrov, P.G.; Skachkov, B.I. Kamennaya Steppe: Agroforestry Landscapes; Voronezh State University Press: Voronezh, Russian, 1992; p. 224. (In Russian)

5. Erusalimskii, V.I. State protective windbreaks as a part of the protective forest plantations. In Variety of Soils in the Kamennaya Steppe; Soil Institute of V.V. Dokuchaev: Moscow, Russian, 2009; pp. 387-405. (In Russian)

6. Akhtyrtsev, B.P.; Solovichenko, V.D. Soil Cover of Belgorod Oblast: Structure, Zoning, and Rational Management; Voronezh State University Press: Voronezh, Russian, 1984; p. 224. (In Russian)

7. Zagorovsky, V.P. The History of the Central Chernozem Region Joining to the Russian State in the XVI Century; Voronezh State University: Voronezh, Russian, 1991; p. 270. (In Russian)

8. Wrangel, V. The History of Forest Legislation of the Russian Empire with Assay of the Russian Ship Timbers; Printing house of Fisher: Saint Petersburg, Russian, 1844; p. 153. (In Russian)

9. Myl'kov, F.N., Ed. Central Russian “Belogorye”; Voronezh State University Press: Voronezh, Russian, 1985; p. 238. (In Russian) 
10. Chendev, Y.G.; Petin, A.N. Natural Changes and Anthropogenic Transformation of the Environmental Components in Regions with Old History of Mastery (for the Example of Belgorod Oblast); Moscow State University Press: Moscow, Russian, 2006; p. 124. (In Russian)

11. Slobodchikov, D.Y., Ed. Agricultural Activity in Russia; Publication of the Department of Agriculture: Petrograd, Russia, 1914; p. 252. (In Russian)

12. Akulov, P.G.; Azarov, B.F.; Shelganov, I.I.; Yavtushenko, V.E. Soil-Agrochemical Bases of Crop Farming Stability in the Central Chernozem Zone; Agropromizdat: Moscow, Russian, 1991; p. 142. (In Russian)

13. Chendev, Y.G.; Aleksandrovskii, A.L.; Khohlova, O.S.; Smirnova, L.G.; Novykh, L.L.; Dolgikh, A.V. Anthropogenic evolution of dark gray forest soils in the Southern Part of the Central Russian Upland. Eurasian Soil Sci. 2011, 1, 3-15.

14. Brandle, J.R.; Hodges, L.; Zhou, X.H. Windbreaks in North American agricultural systems. Agrofor. Syst. 2004, 61, 65-78.

15. Read, R.A. The Great Plains Shelterbelt in 1954 (A Re-Evaluation of Field Windbreaks Planted between 1935 and 1942 and a Suggested Research Program); Great Plains Agricultural Council Publication. No. 16; Nebraska Agricultural Experiment Station: Lincoln, NE, USA, 1958; p. 125.

16. Hernandez-Ramirez, G.; Sauer, T.J.; Cambardella, C.; Brandle, J.R.; James, D.E. Carbon sources and dynamics in afforested and cultivated Corn Belt soils. Soil Sci. Soc. Am. J. 2011, 75, 216-225.

17. Kort, J.; Turnock, R. Carbon Reservoir and biomass in Canadian prairie shelterbelts. Agrofor. Syst. 1999, 44, 175-186.

18. Sauer, T.J.; Cambardella, C.A.; Brandle, R.B. Soil carbon and tree litter dynamics in a red cedar-scotch pine shelterbelt. Agrofor. Syst. 2007, 71, 163-174.

19. Sauer, T.J.; Nelson, M.P. Science, ethics, and the historical roots of our ecological crisis: Was white right? In Sustaining Soil Productivity in Response to Global Climate Change: Science, Policy, and Ethics; Villey-Blackwell: Chichester, UK, 2011; pp. 3-16.

20. Selyaninov, G.T. On agricultural climate valuation. Proc. Agric. Meteorol. 1928, 20, $165-177$.

21. Chendev, Y.G.; Sauer, T.J.; Hall, R.B.; Petin, A.N.; Novykh, L.L.; Zazdravnykh, E.A.; Cheverdin, Y.I.; Tischenko, V.V.; Filatov, K.I. Stock assessment and balance of organic carbon in the Eastern European forest-steppe ecosystems tree windbreaks. Reg. Environ. Issues 2013, 4, 7-14. (In Russian)

22. Al'benskiy, A.B. Afforestation and environmental change. Gerald Agric. Sci. 1961, 2, 96-101. (In Russian)

23. Tumin, G.M. Impact of Shelterbelts to Soil in Kamennaya Steppe; Kommuna: Voronezh, Russian, 1930; p. 40. (In Russian)

24. Kaganov, V.V. Change in carbon stocks of ecosystems under afforestation within steppe and semi-desert zones of the European Russia. Reg. Environ. Issues. 2012, 4, 7-12. (In Russian)

25. Solovyov, P.E. Influence of Windbreaks to Soil Formation and Fertility of Steppe Soils; Moscow State University Press: Moscow, Russian, 1967; p. 200. (In Russian) 
26. Sauer, T.J.; James, D.E.; Cambardella, C.A.; Hernandez-Ramirez, G. Soil properties following restoration or afforestation of marginal cropland. Plant Soil. 2012, 360, 1-2.

(C) 2015 by the authors; licensee MDPI, Basel, Switzerland. This article is an open access article distributed under the terms and conditions of the Creative Commons Attribution license (http://creativecommons.org/licenses/by/4.0/). 